\title{
ON $\boldsymbol{H}$-IRREGULARITY STRENGTH OF GRAPHS
}

\author{
FARAHA ASHRAF \\ Abdus Salam School of Mathematical Sciences \\ GC University, Lahore, Pakistan \\ e-mail: faraha27@gmail.com \\ MARTIN BAČA ${ }^{1}$ \\ MarCela LascsáKovÁ \\ AND \\ Andrea Semaničová-FeñovČíKovÁ \\ Department of Applied Mathematics and Informatics \\ Technical University, Košice, Slovakia \\ e-mail: martin.baca@tuke.sk \\ marcela.lascsakova@tuke.sk \\ andrea.fenovcikova@tuke.sk
}

\begin{abstract}
New graph characteristic, the total $H$-irregularity strength of a graph, is introduced. Estimations on this parameter are obtained and for some families of graphs the precise values of this parameter are proved.
\end{abstract}

Keywords: $H$-covering, $H$-irregular labeling, $H$-irregularity strength.

2010 Mathematics Subject Classification: 05C78, 05C70.

\section{REFERENCES}

[1] A. Ahmad, M. Bača and M.K. Siddiqui, On edge irregular total labeling of categorical product of two cycles, Theory Comput. Syst. 54 (2014) 1-12. doi:10.1007/s00224-013-9470-3

[2] M. Aigner and E. Triesch, Irregular assignments of trees and forests, SIAM J. Discrete Math. 3 (1990) 439-449. doi:10.1137/0403038

\footnotetext{
${ }^{1}$ Corresponding author.
} 
[3] D. Amar and O. Togni, Irregularity strength of trees, Discrete Math. 190 (1998) 15-38. doi:10.1016/S0012-365X(98)00112-5

[4] M. Anholcer and C. Palmer, Irregular labellings of circulant graphs, Discrete Math. 312 (2012) 3461-3466. doi:10.1016/j.disc.2012.06.017

[5] M. Bača, S. Jendrol', M. Miller and J. Ryan, On irregular total labellings, Discrete Math. 307 (2007) 1378-1388. doi:10.1016/j.disc.2005.11.075

[6] M. Bača and M.K. Siddiqui, Total edge irregularity strength of generalized prism, Appl. Math. Comput. 235 (2014) 168-173. doi:10.1016/j.amc.2014.03.001

[7] T. Bohman and D. Kravitz, On the irregularity strength of trees, J. Graph Theory 45 (2004) 241-254. doi:10.1002/jgt.10158

[8] S. Brandt, J. Miškuf and D. Rautenbach, On a conjecture about edge irregular total labellings, J. Graph Theory 57 (2008) 333-343. doi:10.1002/jgt.20287

[9] G. Chartrand, M.S. Jacobson, J. Lehel, O.R. Oellermann, S. Ruiz and F. Saba, Irregular networks, Congr. Numer. 64 (1988) 187-192.

[10] R.J. Faudree, M.S. Jacobson, J. Lehel and R.H. Schlep, Irregular networks, regular graphs and integer matrices with distinct row and column sums, Discrete Math. 76 (1988) 223-240. doi:10.1016/0012-365X(89)90321-X

[11] A. Frieze, R.J. Gould, M. Karoński and F. Pfender, On graph irregularity strength, J. Graph Theory 41 (2002) 120-137. doi:10.1002/jgt.10056

[12] J.A. Gallian, Graph labeling, Electron. J. Combin. 17 (2014) 1-389.

[13] K.M.M. Haque, Irregular total labellings of generalized Petersen graphs, Theory Comput. Syst. 50 (2012) 537-544. doi:10.1007/s00224-011-9350-7

[14] J. Ivančo and S. Jendrol', Total edge irregularity strength of trees, Discuss. Math. Graph Theory 26 (2006) 449-456. doi:10.7151/dmgt.1337

[15] S. Jendrol', J. Miškuf and R. Soták, Total edge irregularity strength of complete and complete bipartite graphs, Electron. Notes Discrete Math. 28 (2007) 281-285. doi:10.1016/j.endm.2007.01.041

[16] S. Jendrol', J. Miškuf and R. Soták, Total edge irregularity strength of complete graphs and complete bipartite graphs, Discrete Math. 310 (2010) 400-407. doi:10.1016/j.disc.2009.03.006 
[17] M. Kalkowski, M. Karoński and F. Pfender, A new upper bound for the irregularity strength of graphs, SIAM J. Discrete Math. 25 (2011) 1319-1321. doi:10.1137/090774112

[18] P. Majerski and J. Przybyło, On the irregularity strength of dense graphs, SIAM J. Discrete Math. 28 (2014) 197-205. doi:10.1137/120886650

[19] T. Nierhoff, A tight bound on the irregularity strength of graphs, SIAM J. Discrete Math. 13 (2000) 313-323. doi: $10.1137 /$ S0895480196314291

[20] Nurdin, A.N.M. Salman and E.T. Baskoro, The total edge-irregular strengths of the corona product of paths with some graphs, J. Combin. Math. Combin. Comput. 65 (2008) 163-175.

Received 2 May 2016 Accepted 1 September 2016 